\title{
Quality of life, health, eating habits and physical development of middle school adolescents in the Świetokrzyskie
}

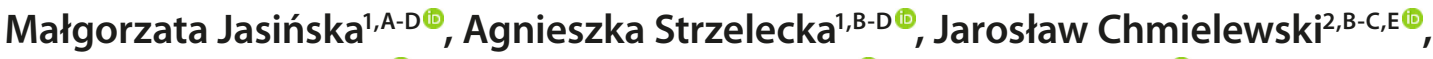 \\ Przemysław Wolak ${ }^{1, C, E \oplus}{ }^{\oplus}$, Iwona Stanisławska ${ }^{2, B, D-E}{ }^{\circ}$, Piotr Choina ${ }^{3, B, E}{ }^{\oplus}$, Marta Kordyzon ${ }^{1, B-C} \odot$,

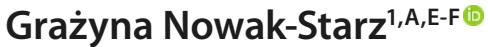 \\ ${ }^{1}$ Collegium Medicum, Jan Kochanowski University, Kielce, Poland \\ ${ }^{2}$ College of Rehabilitation, Warsaw, Poland \\ ${ }^{3}$ Department of Medical Anthropology, Institute of Rural Health, Lublin, Poland \\ A - Research concept and design, B - Collection and/or assembly of data, C - Data analysis and interpretation, \\ $D$ - Writing the article, E-Critical revision of the article, F- Final approval of the article
}

Jasińska M, Strzelecka A, Chmielewski J, Wolak P, Stanisławska I, Choina P, Kordyzon M, Nowak-Starz G. Quality of life, health, eating habits and physical development of middle school adolescents in the Świetokrzyskie. Ann Agric Environ Med. 2021; 28(4): 659-666. doi: $10.26444 /$ aaem/141624

\begin{abstract}
Introduction and objective. Measurement of the health-related quality of life is currently one of the significant methods of self-evaluation of heath, enabling the detection of disorders in the biopsychosocial functioning of children and adolescents. The aim of the study was to establish significant relationships between the subjective sense of the health-related quality of life, eating habits and objective parameters of physical development among a group of adolescents.

Materials and method. The study applied a diagnostic survey methodology with the use of the KIDSCREEN-52 questionnaire, the Health Behaviour in School-aged Children (HBSC) questionnaire, anthropometric measures of choice, and a selfconstructed questionnaire. The significance level was set at $p<0.05$. The collected data was gathered and analyzed using Statistica 10.0 PL.

Results. Three distinct groups of adolescents with a varying subjective sense of the quality of life were identified. The frequency of basic meal consumption among participants showed some abnormalities. This concerned breakfast in particular, which was consumed before going to school by over half of the participants (63.61\%), with boys (70.07\%) eating it significantly more frequently than girls (57.83\%). Indices based on weight-to-height ratios, such as: BMI, Rohrer's Index and Slender Index were significantly greater in value among boys compared with girls.

Conclusions. Adolescents from the Świętokrzyskie region, for the most part exhibited a high subjective sense of the quality of life. The physical development of the participants, as far as basic anthropometric characteristics are concerned, was mostly appropriate and consistent with a high subjective sense of the quality of life and exhibited eating habits.
\end{abstract}

\section{Key words}

quality of life, adolescents, eating habits, KIDSCREEN-52, physical development

\section{INTRODUCTION}

The measurement of health-related quality of life is currently one of the significant methods of self-evaluation of heath, enabling the detection of disorders in the biopsychosocial functioning of children and adolescents [1]. The quality of life is an important element in the evaluation of people's health conditions and concentrates on both physical and mental health. The World Health Organization (WHO) indicates that the quality of life should be evaluated in four dimensions: the area of physical health, psychological, social and environmental relations $[2,3]$. The term Health Related Quality of Life (HRQOL) is based on the multi-dimensional approach to the concept of health [4]. Specific definitions are concentrated on dimensions including the subjective evaluation of one's own health condition [5].

The eating behaviours of children and adolescents are a key element of a healthy lifestyle. Environmental, cultural

Address for correspondence: Piotr Choina, Department of Medical Anthropology, Institute of Rural Health, Lublin, Poland

E-mail: choina.piotr@imw.lublin.pl

Received: 02.06.2021; accepted: 26.08.2021; first published: 14.09.2021 and demographic (age and gender) factors, as well as the knowledge of healthy rules of nutrition, have an impact on eating behaviurs. Proper eating habits, which include regular and rational eating, and appropriately balanced meals, have an effect on good fitness and health, while flawed eating in the formative years of one's life is an early risk factor of overweight, obesity and cardiovascular diseases. In the period of adolescence, flawed eating has a detrimental effect not only on the development of a young person, their health, mood and ability to learn, but also their health condition in the later stages of life $[2,6,7]$.

It is exactly the eating habits of parents and guardians that play a decisive role in feeding children and adolescents. What is more, fixed bad eating habits perpetuated in one's childhood and adolescence, often deepened by a dire economic situation in the family, the specifics of their place of residence, advertisements and stress, affects the formation of unhealthy models of eating in adolescents to a significant degree. The basic factors influencing the occurrence of overweight and obesity, especially amont children and teenagers, is the increased consumption of high-energy foods, e.g. fast-foods - products lacking in nutrients, but rich in fats, sugar and salt $[7,8,9]$. 
Development is an inherent element of every living organism and is subject to constant transformation, while the pace of these changes depends on such factors as: lifestyle, outside environmental conditions, and individual genetic properties. Healthy development and eating habits determine health and the sense of a good quality of life, which is particularly important in the younger generation in the context of the health of future generations $[9,10]$.

The KIDSCREEN general measures of health-related quality of life amont children and adolescents were developed as part of the European project: Screening and Promotion for Health-related Quality of Life in Children and Adolescents - A European Public Health Perspective. The physical, mental, social, psychological and behavioural aspects of well-being were distinguished as components. Emphasis was placed on the multidimensional nature of the quality of life, as well as the subjective evaluation of one's own well-being [1, 6, 11-15].

\section{OBJECTIVE}

The aim of the study was to establish the relationship between the subjective sense of the quality of life related to health, eating habits and objective parameters of physical development amongst a group of adolescents.

\section{MATERIALS AND METHOD}

In Poland, when it comes to the postulates of the subsequent editions of the National Health Programme, the effects of monitoring the lifestyle and physical development of children and adolescents are believed to be an important indicator of the quality of life in health, and a significant element of its promotion. As is known, social gradients are invariably connected with the state of health, and living conditions reflect the scale of improvement or deterioration of the conditions of the ontogenetic development of a population at developmental age. There are disparities in Poland in the health of children and adolescents which are caused by living in different material and environmental conditions, and geographical regions. The afore-mentioned phenomena are decidedly more frequent in the area of the so-called Poland B, meaning the eastern block, which encompasses the Podlaskie, Lubelskie, Podkarpackie, Świętokrzyskie, and Warmińsko-Mazurskie provincves.

For the purposes of the study, it was arbitrarily decided to select one of the provinces of the so-called Poland B before a random selection was made, and each record in the database which held the names of the provinces was coded with a unique ID number as a blinded trial. The procedure was performed based on a random choice operation from the R-project, which is a mathematical package designed for advanced statistical calculations. It is distributed under the GPL license, meaning the programme is entirely free and can be used by researchers. The province selected through random choice was the Świętokrzyskie province, and it was in this region that the representative studies were carried out, and served as the basis for analysing the phenomena regarding the lifestyle and the physical development of children and adolescents.

Cluster sampling was used in the sample selection, with the stratification of the location of schools and classes. In the first stage of the research, a list of 244 middle schools for children and adolescents (excluding special schools) in the Swiętokrzyskie province was prepared on the basis of data from the Office of Education in Kielce. Each institution was assigned an individual code. Three middle schools were randomly selected, one from the city of Kielce, and two middle schools outside of Kielce, i.e., from the towns of Chmielnik and Piekoszów. In the second stage, random sampling of classes took place. Forty-two classes were randomly selected in total, with 14 classes per school. After receiving written consent from parents, a list of names and surnames of the total 1117 students from the 42 classes (base) was prepared, including 488 boys and 629 girls. In view of the greater number of girls in the study group, in order to ensure a $95 \%$ confidence level with a $5 \%$ maximum error, 871 students were randomly selected from the prepared database, including 411 boys (47.19\%) and 460 girls (52.81\%), aged 13-16, residing in the Świętokrzyskie province (Tab. 1).

The study used the diagnostic survey methodology. The health-related quality of life was measured with the Polish version of the KIDSCREEN-52 questionnaire (Healthrelated Quality of Life Screening Instrument for Children and Adolescents), developed by the KIDSCREEN GROUP EUROPE, after obtaining prior consent to use it. The KIDSCREEN-52 questionnaire is an international research tool designed to examine the health-related quality of life of children and adolescents between the ages of 8-18. The KIDSCREEN-52 questionnaire adapted the principle of answering questions in reference to the timeframe of the last week and a standardized, 5-point response scale for frequency - from never to always (never, seldom, quite often, very often, always) - and intensity of the variable - from not at all to extremely (not at all, slightly, moderately, very, extremely). Responses were scored from 0-4.

The second tool was the HBSC (Health Behaviour in School-aged Children) questionnaire; some questions from the Polish version of the standard HBSC questionnaire were

Table 1. Characteristics of the sample

\begin{tabular}{|c|c|c|c|c|c|c|}
\hline \multirow{2}{*}{ Gender } & \multirow{2}{*}{ Residence } & \multicolumn{4}{|c|}{ Age (years) } & \multirow{2}{*}{ Total } \\
\hline & & 13 & 14 & 15 & 16 & \\
\hline \multirow{2}{*}{ Boys } & city & $19(11.52 \%)$ & $55(33.33 \%)$ & $57(34.55 \%)$ & 34 (20.61\%) & 165 (18.94\%) \\
\hline & countryside & $56(22.76 \%)$ & $64(26.02 \%)$ & $72(29.27 \%)$ & 54 (21.95\%) & $246(28.25 \%)$ \\
\hline Total participants & & 75 (8.61\%) & $11(13.66 \%)$ & $129(14.81 \%)$ & $88(10.10 \%)$ & 411 (47.19\%.) \\
\hline Girls & city & $28(16.00 \%)$ & $50(28.57 \%)$ & $59(33.71 \%)$ & $38(21.71 \%)$ & 175 (20.09\%) \\
\hline Total girls & & 82 (9.41\%.) & 146 (16.76\%) & 148 (16.99\%) & 84 (9.64\%) & $460(52.81 \%)$ \\
\hline Total participants & & $157(18.03 \%)$ & $265(30.42 \%)$ & 277 (31.80\%) & 172 (19.75\%) & $871(100.00 \%)$ \\
\hline
\end{tabular}


used to evaluate the eating habits of adolescents. Different aspects of eating habits were examined for the participating students: dietary pattern, basic meal frequency, snacking between basic meal frequency, and the snacking pattern. For the purpose of the presented study, the eating patterns were examined qualitatively. Only 4 groups of questions from the HBSC questionnaire were used, relating to different aspects of eating habits: dietary pattern, basic meal frequency, snacking between basic meal frequency and the snacking pattern. The first group of HBSC questions concerned the frequency of healthy and unhealthy food product consumption in the last week. Healthy food products included: fruits, vegetables, milk and dairy products (natural yoghurt, kefir, white cheese), dark bread, while unhealthy products included: sweets (candy, chocolate, bars), drinking Coca-Cola or other fizzy soft drinks, eating crisps. The second group of HBSC questions concerned the frequency of basic meal consumption throughout the week, on school days and at the weekends. For school days, the possible responses were never; 1-2 times a week; 3-4 times a week, 5 times a week, while on the weekends the possible responses were: never, once (on one day of the weekend), twice (on both days of the weekend). The third group of HBSC questions was concerned with the frequency of snacking between meals throughout the week, on school days and at the weekends. The possible responses were never, seldom, sometimes, often. The fourth group of HBSC questions was concerned with the frequency of consuming snacks, i.e., snacking patterns between basic meals, a healthy or unhealthy nature of the assortment, the choice of snacks during the week. The possible responses were never, seldom, sometimes, often. Healthy food products included: sandwiches, fruits, vegetables, natural yoghurts and kefirs, while unhealthy products included: sweets (candy, chocolate, bars), pastries or cake, breadsticks and crisps.
The studies were carried out in the period between October 2018 - April 2019 in accordance with the approval from the Bioethical Commission of the Jan Kochanowski University in Kielce (No. 04/2009).

Statistical analysis. While carrying out statistical analysis of the collected data for the dimensions of the subjective sense of the quality of life, arithmetical means (mean results of HRQOL indices on a total scale of $0-100$ points) and standard deviation were given, and the Kruskal-Wallis and Mann-Whitney U non-parametric tests were applied. For qualitative variables, their distribution and frequency were given. To examine the relationships between Body Mass Index (BMI), groups of subjective sense of the quality of life $(F)$, dietary and snacking patterns, meal and snacking frequencies and somatic parameters of participants, nonparametric $r$-Spearman correlations were applied.

Assuming the significance level $p<0.05$, analysis of the data was carried out using Statistica 10.0 PL software.

\section{RESULTS}

Three distinct groups of adolescents with a varying subjective sense of the quality of life were identified. In accordance with the KIDSCREEN GROUP EUROPE guidelines, the HRQOL index was calculated for each participant (score range 0-100) (Tab. 2).

Participants in Group I had the highest evaluations of the quality of their life in all dimensions of the KIDSCREEN-52 questionnaire, where other than the dimension of social acceptance, they also highly evaluated the relationships with their parents and home life, as well as their moods and emotions. The lowest evaluated dimension in Group I was the

Table 2. Groups of adolescents with a varying subjective sense of the quality of life and quality of life dimensions

\begin{tabular}{|c|c|c|c|c|}
\hline \multirow[t]{2}{*}{ Quality of life dimension/Dimension characteristic according to THE KIDSCREEN GROUP EUROPE } & $\begin{array}{l}\text { Group I** } \\
(\mathrm{n}=383)\end{array}$ & $\begin{array}{c}\text { Group } I^{* *} \\
(\mathrm{n}=339)\end{array}$ & $\begin{array}{c}\text { Group III** } \\
(n=149)\end{array}$ & \multirow[t]{2}{*}{$p=$ value $^{*}$} \\
\hline & $M(S D)$ & $M(S D)$ & $\mathrm{M}(\mathrm{SD})$ & \\
\hline $\begin{array}{l}\text { Level of child's/ adolescent's physical activity, energy and overall fitness on the basis of evaluating the ability } \\
\text { to navigate their close environment, ability to play and perform sport. }\end{array}$ & $80.74 \pm 12.30$ & $70.37 \pm 12.32$ & $61.96 \pm 14.10$ & 0.000 \\
\hline $\begin{array}{l}\text { Psychological Well-being (feelings). Psychological well-being, including the aspects of positive emotions and } \\
\text { satisfaction with life. Experiencing positive feelings: happiness, joy, serenity. }\end{array}$ & $84.13 \pm 11.76$ & $73.12 \pm 12.65$ & $59.06 \pm 17.06$ & 0.000 \\
\hline $\begin{array}{l}\text { Moods and Emotions (overall mood). Experiencing depressed moods and feelings of stress, an intensified } \\
\text { feeling of loneliness, sadness and hopelessness. }\end{array}$ & $88.55 \pm 10.06$ & $80.99 \pm 11.35$ & $69.09 \pm 16.75$ & 0.000 \\
\hline $\begin{array}{l}\text { Self-Perception. } \\
\text { Judgement of one's appearance, feeling of contentment/discontentment about one's appearance, care for } \\
\text { one's appearance and potential desire to change it. }\end{array}$ & $80.28 \pm 15.07$ & $72.01 \pm 13.18$ & $59.44 \pm 13.70$ & 0.000 \\
\hline $\begin{array}{l}\text { Autonomy (free time). } \\
\text { Having free time and some degree of autonomy in building social relationships through free time. }\end{array}$ & $84.05 \pm 12.88$ & $69.54 \pm 13.49$ & $51.81 \pm 15.10$ & 0.000 \\
\hline \multicolumn{5}{|l|}{ Financial Resources. } \\
\hline $\begin{array}{l}\text { Family's financial resources, financial limitations in terms of access to entertainment, purchasing of certain } \\
\text { goods, leading a lifestyle similar to that of one's peers. }\end{array}$ & $85.64 \pm 12.80$ & $67.98 \pm 15.50$ & $45.46 \pm 16.15$ & 0.000 \\
\hline \multicolumn{5}{|l|}{ Peers and Social Support (friends and peers). } \\
\hline $\begin{array}{l}\text { Child's/adolescent's relationship with their peers, acknowledgment of social support, level of social } \\
\text { acceptance, belonging to the peer group }\end{array}$ & $85.57 \pm 10.99$ & $70.63 \pm 12.81$ & $54.63 \pm 16.96$ & 0.000 \\
\hline
\end{tabular}


dimension of school environment. Adolescents in Group II, aside from social acceptance, reported a high evaluation of the dimension of moods and emotions, parent relations and home life, relationships with parents, while evaluating the school environment dimension the lowest. Pupils in Group III, aside from the dimension of social acceptance, evaluated the dimensions of moods and emotions, physical well-being, psychological well-being and self-perception the highest, while evaluating the dimensions of autonomy and financial resources the lowest. Statistically significant differences $(\mathrm{p}=0.000)$ between the 9 dimensions of the evaluation of the quality of life were shown (T. 2).

As far as the dietary patterns of adolescents are concerned, the least proper eating habits were observed (0.11\%). $71.52 \%$ of the adolescents surveyed ate breakfast, lunch and dinner regularly (combined data concerning proper eating habits and tendency towards proper eating habits). Every tenth participant (10.38\%) exhibited improper eating habits and simultaneously a tendency towards improper eating habits. Every fifth participant (19.85\%) did not snack between basic meals, and improper eating habits in that area were observed in half of the participants. The snacking patterns showed the greatest occurrence of neutral eating habits (64.06\%) (Tab. 3). Eating habits related to basic meal frequency $(\mathrm{p}=0.002)$ and snacking patterns $(\mathrm{p}=0.009)$ had a significant relationship with the subjective sense of the quality of life in the adolescents studied. However, there was no statistically significant relationship found between dietary patterns $(\mathrm{p}=0.991)$ or snacking frequency $(\mathrm{p}=0.732)$ and the subjective sense of the quality of life of participants. Too few adolescents ate wholemeal and multigrain bread, only $4.15 \%$ of boys and $4.13 \%$ of girls ate wholemeal bread more than once every day, whereas $25.29 \%$ of participants did not eat it at all, with $24.39 \%$ of boys and $26.09 \%$ of girls admitted to not eating this type of bread. Evaluating the frequency of fizzy soft drinks and sweets consumption in participants, it was found that $13.41 \%$ of boys and $11.09 \%$ of girls drank soft drinks more than once every day. Analysis of the effect of gender on the consumption of fizzy soft drinks showed statistical significance $(\mathrm{p}=0.002)$. Girls ate more sweets once a day every day $(20.65 \%)$ than boys (12.20\%). It was shown that girls eat sweets significantly more than boys $(\mathrm{p}=0.000)$.

Table 3. Relationship between dietary and snacking patterns and eating habits of participants according to the HBSC questionnaire

\begin{tabular}{lccccc}
\hline \multirow{2}{*}{$\begin{array}{l}\text { Dietary/snacking } \\
\text { patterns }\end{array}$} & $\begin{array}{c}\text { PEH } \\
n\end{array}$ & $\begin{array}{c}\text { TPEH } \\
\mathrm{n}(\%)\end{array}$ & $\begin{array}{c}\mathrm{NEH} \\
\mathrm{n}(\%)\end{array}$ & $\begin{array}{c}\text { TIEH } \\
\mathrm{n}(\%)\end{array}$ & $\begin{array}{c}\text { IEH } \\
\mathrm{n}(\%)\end{array}$ \\
\hline Dietary patterns & $1(0.11)$ & $201(23.08)$ & $535(61.43)$ & $131(15.04)$ & $3(0.34)$ \\
\hline $\begin{array}{l}\text { Basic meal } \\
\text { frequency }\end{array}$ & $379(43.51)$ & $244(28.01)$ & $155(17.80)$ & $87(9.99)$ & $6(0.39)$ \\
\hline $\begin{array}{l}\text { Snacking } \\
\text { frequency }\end{array}$ & $173(19.86)$ & $0(0.00)$ & $211(24.23)$ & $0(0.00)$ & $\begin{array}{c}487 \\
(55.91)\end{array}$ \\
\hline $\begin{array}{l}\text { Snacking } \\
\text { patterns }\end{array}$ & $67(7.69)$ & $0(0.00)$ & $558(64.06)$ & $0(0.00)$ & $\begin{array}{c}246 \\
(28.24)\end{array}$ \\
\hline
\end{tabular}

PEH - proper eating habits.; TPEH - tendency towards proper eating habits; NEH - neutral eating habits; TIEH - tendency towards improper eating habits; IEH - improper eating habits

Family meals are an important element in the functioning of a family and enable the formation of beneficial eating behaviours and habits in adolescents, including eating breakfast. It was proven that adolescents who skip breakfast before leaving the house, compensated for the fact by eating more food during the day.

Analysing the relationship between the subjective sense of the quality of life and BMI, it was found that participants exhibiting a high $(78.85 \%)$, medium $(78.17 \%)$, as well as low (85.91\%) subjective sense of the quality of life, had normal BMI results (79.79\%) The highest incidence of overweight participants was found in the group with a medium subjective sense of the quality of life (10.03\%). Obesity concerned mostly adolescents with a high subjective sense of the quality of life $(9.66 \%)$. Data analysis showed that a small percentage of participants were underweight $(2.53 \%)$, most of whom were in the group with the medium subjective sense of the quality of life $(2.95 \%)$, and the least of whom were in the group with a low subjective sense of the quality of life (0.67\%) (Tab. 4).

Table 4. Subjective sense of the quality of life in relation to participant BMI

\begin{tabular}{lcccc}
\hline Participant BMI* & $\begin{array}{c}\text { Group I** } \\
\mathrm{n}(\%)\end{array}$ & $\begin{array}{c}\text { Group I** } \\
\mathrm{n}(\%)\end{array}$ & $\begin{array}{c}\text { Group III** } \\
\mathrm{n}(\%)\end{array}$ & $\begin{array}{c}\text { Total } \\
\mathrm{n}(\%)\end{array}$ \\
\hline Underweight & $11(2.87)$ & $10(2.95)$ & $1(0.67)$ & $22(2.53)$ \\
\hline Normal & $302(78.85)$ & $265(78.17)$ & $128(85.91)$ & $695(79.79)$ \\
\hline Overweight & $33(8.62)$ & $34(10.03)$ & $8(5.37)$ & $75(8.61)$ \\
\hline Obesity & $37(9.66)$ & $30(8.85)$ & $12(8.05)$ & $79(9.07)$ \\
\hline Total & $383(100.00)$ & $339(100.00)$ & $149(100.00)$ & $871(100.00)$
\end{tabular}

* Underweight: BMI $<5$ percentile; normal (proper body weight): BMI $5 \geq 85$ percentile; overweight: BMI 85-95 percentile; obesity: BMI $\geq 95$ percentile.

** Group I - high subjective sense of the quality of life; Group II - medium subjective sense of the quality of life; Group III - low subjective sense of the quality of life.

Significant differences in terms of body height were observed among $14-(p=0.001), 15-(p=0.001)$ and 16$(\mathrm{p}=0.000)$ year-old participants. Boys were significantly taller than girls. No significant differences in height were observed in 13-year-old participants. At the ages of 14 and 15 , boys also reached a significantly higher body weight. The differences in means between genders were $3.99 \mathrm{~kg}$ and $3.55 \mathrm{~kg}$ for 14- and 15-year-olds, respectively. Indices based on weight-to-height ratios, such as: BMI, Rohrer's Index and Slender Index, were significantly greater in value among boys, compared with girls, and were related to 15- and 16-year-old teenagers only (Tab. 5).

Before carrying out the Spearman correlation, the results for the analysed characteristics were normalised for the age and gender of participants. The correlation between body weight and BMI was strong and showed that body weight increases proportionally to BMI. The correlation of body weight and dietary patterns, however, turned out to be negative; therefore, the greater the BMI the greater the body weight and the lower the evaluation of dietary patterns. A similar relationship between BMI and dietary patterns was exhibited by the sum of 3 site skinfolds, adipose tissue (kg), Rohrer's Index and body density. Slender Index showed a negative strong correlation with BMI and a positive correlation with dietary patterns (Tab. 6).

To sum-up the above analyses of the spatial relationships between physical development, dietary patterns, snacking patterns, snacking frequency, basic meal frequency and the subjective sense of the quality of life in accordance with the KIDSCREEN-52 questionnaire, it has to be highlighted that there is a significant impact of eating habits in the formation of the quality of life related to the health of adolescents. The interactions and conditions determining the physical 
Table 5. Basic somatic characteristics in relation to gender and age of participants

\begin{tabular}{|c|c|c|c|c|c|c|}
\hline \multirow{2}{*}{ Characteristic } & \multirow{2}{*}{ Age } & \multicolumn{2}{|c|}{ Boys } & \multicolumn{2}{|c|}{ Girls } & \multirow{2}{*}{$p$-value } \\
\hline & & $M(S D)$ & $\mathrm{Me}(\mathrm{IQR})$ & $M(S D)$ & Me (IQR) & \\
\hline \multirow{4}{*}{$\begin{array}{l}\text { Body height } \\
(\mathrm{cm})\end{array}$} & 13 & $\begin{array}{c}160.61 \\
(8.20)\end{array}$ & $\begin{array}{l}161.00 \\
(10.00)\end{array}$ & $\begin{array}{c}159.68 \\
(6.33)\end{array}$ & $\begin{array}{l}159.50 \\
(8.00)\end{array}$ & 0.448 \\
\hline & 14 & $\begin{array}{c}166.35 \\
(9.53)\end{array}$ & $\begin{array}{l}167.00 \\
(12.00)\end{array}$ & $\begin{array}{c}161.24 \\
(6.04)\end{array}$ & $\begin{array}{c}161.00 \\
(8.00)\end{array}$ & 0.001 \\
\hline & 15 & $\begin{array}{c}168.94 \\
(8.79)\end{array}$ & $\begin{array}{l}170.00 \\
(11.50)\end{array}$ & $\begin{array}{l}162.86 \\
(6.94)\end{array}$ & $\begin{array}{c}162.00 \\
(9.00)\end{array}$ & 0.001 \\
\hline & 16 & $\begin{array}{c}166.92 \\
(9.72)\end{array}$ & $\begin{array}{l}167.00 \\
(16.50)\end{array}$ & $\begin{array}{c}161.92 \\
(7.07)\end{array}$ & $\begin{array}{l}161.00 \\
(9.00)\end{array}$ & 0.000 \\
\hline \multirow{4}{*}{$\begin{array}{l}\text { Body weight } \\
(\mathrm{kg})\end{array}$} & 13 & $\begin{array}{c}54.09 \\
(13.14)\end{array}$ & $\begin{array}{c}50.00 \\
(21.00)\end{array}$ & $\begin{array}{l}51.65 \\
(9.56)\end{array}$ & $\begin{array}{c}50.00 \\
(10.50)\end{array}$ & 0.645 \\
\hline & 14 & $\begin{array}{c}57.37 \\
(11.71)\end{array}$ & $\begin{array}{c}57.00 \\
(15.00)\end{array}$ & $\begin{array}{l}53.38 \\
(9.60)\end{array}$ & $\begin{array}{c}51.50 \\
(11.00)\end{array}$ & 0.001 \\
\hline & 15 & $\begin{array}{c}58.86 \\
(12.85)\end{array}$ & $\begin{array}{c}58.00 \\
(13.00)\end{array}$ & $\begin{array}{l}55.31 \\
(8.88)\end{array}$ & $\begin{array}{c}54.00 \\
(10.00)\end{array}$ & 0.008 \\
\hline & 16 & $\begin{array}{c}56.51 \\
(10.48)\end{array}$ & $\begin{array}{c}55.50 \\
(13.75)\end{array}$ & $\begin{array}{l}54.39 \\
(8.49)\end{array}$ & $\begin{array}{c}52.50 \\
(11.00)\end{array}$ & 0.197 \\
\hline \multirow{4}{*}{ BMI } & 13 & $\begin{array}{l}20.81 \\
(4.15)\end{array}$ & $\begin{array}{l}19.29 \\
(4.94)\end{array}$ & $\begin{array}{l}20.20 \\
(3.19)\end{array}$ & $\begin{array}{l}19.46 \\
(2.79)\end{array}$ & 0.963 \\
\hline & 14 & $\begin{array}{l}20.59 \\
(3.04)\end{array}$ & $\begin{array}{l}20.28 \\
(2.92)\end{array}$ & $\begin{array}{l}20.46 \\
(3.04)\end{array}$ & $\begin{array}{l}19.47 \\
(2.91)\end{array}$ & 0.552 \\
\hline & 15 & $\begin{array}{l}20.49 \\
(3.42)\end{array}$ & $\begin{array}{l}19.62 \\
(2.78)\end{array}$ & $\begin{array}{l}20.82 \\
(2.89)\end{array}$ & $\begin{array}{l}19.95 \\
(3.30)\end{array}$ & 0.056 \\
\hline & 16 & $\begin{array}{l}20.17 \\
(2.72)\end{array}$ & $\begin{array}{l}19.09 \\
(2.42)\end{array}$ & $\begin{array}{l}20.69 \\
(2.53)\end{array}$ & $\begin{array}{l}20.03 \\
(2.97)\end{array}$ & 0.026 \\
\hline \multirow{4}{*}{$\begin{array}{l}\text { Sum of } 3 \text { site } \\
\text { skinfolds } \\
(\mathrm{mm})\end{array}$} & 13 & $\begin{array}{c}34.99 \\
(17.31)\end{array}$ & $\begin{array}{c}26.00 \\
(20.00)\end{array}$ & $\begin{array}{c}38.85 \\
(12.24)\end{array}$ & $\begin{array}{l}36.00 \\
(8.00)\end{array}$ & 0.001 \\
\hline & 14 & $\begin{array}{c}33.17 \\
(12.95)\end{array}$ & $\begin{array}{c}27.50 \\
(10.00)\end{array}$ & $\begin{array}{c}39.66 \\
(12.18)\end{array}$ & $\begin{array}{l}36.00 \\
(9.00)\end{array}$ & 0.001 \\
\hline & 15 & $\begin{array}{c}32.02 \\
(13.84)\end{array}$ & $\begin{array}{c}26.00 \\
(10.00)\end{array}$ & $\begin{array}{c}41.05 \\
(11.57) \\
\end{array}$ & $\begin{array}{c}37.00 \\
(12.00)\end{array}$ & 0.001 \\
\hline & 16 & $\begin{array}{c}31.05 \\
(11.45)\end{array}$ & $\begin{array}{l}26.00 \\
(8.50)\end{array}$ & $\begin{array}{c}40.27 \\
(10.56)\end{array}$ & $\begin{array}{c}37.00 \\
(11.00)\end{array}$ & 0.000 \\
\hline \multirow{4}{*}{$\begin{array}{l}\text { Adipose } \\
\text { tissue } \\
(\mathrm{kg})\end{array}$} & 13 & $\begin{array}{c}3.88 \\
(2.70)\end{array}$ & $\begin{array}{c}2.59 \\
(3.28)\end{array}$ & $\begin{array}{c}4.12 \\
(1.89)\end{array}$ & $\begin{array}{c}3.66 \\
(1.76)\end{array}$ & 0.001 \\
\hline & 14 & $\begin{array}{c}3.94 \\
(2.19)\end{array}$ & $\begin{array}{c}3.26 \\
(2.33)\end{array}$ & $\begin{array}{c}4.34 \\
(1.91)\end{array}$ & $\begin{array}{c}3.73 \\
(1.76)\end{array}$ & 0.005 \\
\hline & 15 & $\begin{array}{c}3.90 \\
(2.58)\end{array}$ & $\begin{array}{c}3.00 \\
(1.95)\end{array}$ & $\begin{array}{c}4.62 \\
(1.76)\end{array}$ & $\begin{array}{c}4.03 \\
(1.62)\end{array}$ & 0.001 \\
\hline & 16 & $\begin{array}{c}3.62 \\
(1.89)\end{array}$ & $\begin{array}{c}2.96 \\
(1.95)\end{array}$ & $\begin{array}{c}4.48 \\
(1.62)\end{array}$ & $\begin{array}{c}3.88 \\
(1.83)\end{array}$ & 0.000 \\
\hline \multirow{4}{*}{$\begin{array}{l}\text { Slender } \\
\text { Index }\end{array}$} & 13 & $\begin{array}{l}42.88 \\
(2.48)\end{array}$ & $\begin{array}{l}43.62 \\
(2.95)\end{array}$ & $\begin{array}{l}43.11 \\
(2.08)\end{array}$ & $\begin{array}{l}43.32 \\
(2.14)\end{array}$ & 0.847 \\
\hline & 14 & $\begin{array}{l}43.40 \\
(1.94)\end{array}$ & $\begin{array}{l}43.66 \\
(2.16)\end{array}$ & $\begin{array}{l}43.04 \\
(1.86)\end{array}$ & $\begin{array}{l}43.41 \\
(2.18)\end{array}$ & 0.159 \\
\hline & 15 & $\begin{array}{l}43.72 \\
(2.08)\end{array}$ & $\begin{array}{l}44.17 \\
(2.17)\end{array}$ & $\begin{array}{l}42.92 \\
(1.94)\end{array}$ & $\begin{array}{l}43.34 \\
(2.35)\end{array}$ & 0.001 \\
\hline & 16 & $\begin{array}{l}43.70 \\
(1.77)\end{array}$ & $\begin{array}{l}43.98 \\
(1.88)\end{array}$ & $\begin{array}{l}42.89 \\
(1.68)\end{array}$ & $\begin{array}{l}43.23 \\
(1.99)\end{array}$ & 0.000 \\
\hline \multirow{4}{*}{$\begin{array}{l}\text { Rohrer's } \\
\text { Index }\end{array}$} & 13 & $\begin{array}{c}1.30 \\
(0.25)\end{array}$ & $\begin{array}{c}1.21 \\
(0.26)\end{array}$ & $\begin{array}{c}1.27 \\
(0.20)\end{array}$ & $\begin{array}{c}1.23 \\
(0.19)\end{array}$ & 0.845 \\
\hline & 14 & $\begin{array}{c}1.24 \\
(0.18)\end{array}$ & $\begin{array}{c}1.20 \\
(0.18)\end{array}$ & $\begin{array}{c}1.27 \\
(0.18)\end{array}$ & $\begin{array}{c}1.22 \\
(0.19)\end{array}$ & 0.160 \\
\hline & 15 & $\begin{array}{c}1.21 \\
(0.19)\end{array}$ & $\begin{array}{c}1.16 \\
(0.18)\end{array}$ & $\begin{array}{c}1.28 \\
(0.19)\end{array}$ & $\begin{array}{c}1.23 \\
(0.21)\end{array}$ & 0.001 \\
\hline & 16 & $\begin{array}{c}1.21 \\
(0.17)\end{array}$ & $\begin{array}{c}1.18 \\
(0.15)\end{array}$ & $\begin{array}{c}1.28 \\
(0.16)\end{array}$ & $\begin{array}{c}1.24 \\
(0.18)\end{array}$ & 0.000 \\
\hline
\end{tabular}

*Mann-Whitney U test
Table 6. Relationships between subjective sense of the quality of life (F), BMI, dietary and snacking patterns, meal and snacking frequency, and somatic characteristics of participants

\begin{tabular}{lcccccc}
\hline Characteristics & $F$ & BMI & $\begin{array}{c}\text { Dietary } \\
\text { patterns }\end{array}$ & $\begin{array}{c}\text { Meal } \\
\text { frequency }\end{array}$ & $\begin{array}{c}\text { Snacking } \\
\text { patterns }\end{array}$ & $\begin{array}{c}\text { Snacking } \\
\text { frequency }\end{array}$ \\
\hline Body height & $\begin{array}{c}0.001 \\
(0.995)\end{array}$ & $\begin{array}{c}0.06 \\
(0.104)\end{array}$ & $\begin{array}{c}-0.02 \\
(0.104)\end{array}$ & $\begin{array}{c}-0.01 \\
(0.804)\end{array}$ & $\begin{array}{c}-0.01 \\
(0.887)\end{array}$ & $\begin{array}{c}0.01 \\
(0.884)\end{array}$ \\
\hline Body weight & 0.01 & $\mathbf{0 . 6 2}$ & $\mathbf{- 0 . 1 3 2}$ & -0.03 & -0.03 & 0.01 \\
& $(0.874)$ & $\mathbf{( 0 . 0 0 1 )}$ & $\mathbf{( 0 . 0 0 1 )}$ & $(0.373)$ & $(0.347)$ & $(0.828)$ \\
\hline Sum of 3 site & 0.01 & $\mathbf{0 . 6 9}$ & $\mathbf{- 0 . 1 4}$ & -0.05 & -0.02 & 0.04 \\
skinfolds & $(0.981)$ & $\mathbf{( 0 . 0 0 1 )}$ & $\mathbf{( 0 . 0 0 1 )}$ & $(0.179)$ & $(0.496)$ & $(0.303)$ \\
\hline Adipose tissue & 0.01 & $\mathbf{0 . 6 0}$ & $\mathbf{- 0 . 1 3}$ & -0.03 & -0.03 & 0.01 \\
(kg) & $(0.830)$ & $\mathbf{( 0 . 0 0 1 )}$ & $\mathbf{( 0 . 0 0 1 )}$ & $(0.395)$ & $(0.358)$ & $(0.826)$ \\
\hline Slender Index & -0.03 & $\mathbf{- 0 . 6 8}$ & $\mathbf{0 . 1 8}$ & 0.031 & 0.02 & -0.03 \\
& $(0.432)$ & $\mathbf{( 0 . 0 0 1 )}$ & $\mathbf{( 0 . 0 0 1 )}$ & $(0.361)$ & $(0.560)$ & $(0.409)$ \\
\hline \multirow{2}{*}{ Rohrer's Index } & 0.03 & $\mathbf{0 . 6 8}$ & $\mathbf{- 0 . 1 2}$ & -0.03 & -0.02 & 0.03 \\
& $(0.436)$ & $\mathbf{( 0 . 0 0 1 )}$ & $\mathbf{( 0 . 0 0 1 )}$ & $(0.371)$ & $(0.532)$ & $(0.409)$
\end{tabular}

development of participants are also important in this period of the ontogenetic development of adolescents.

\section{DISCUSSION}

The quality of life is determined by the functioning of a person; therefore, it is especially important among adolescents to diagnose any relationships between the quality of life and health condition. Negligence in care over children and adolescents at all stages of development has a multitude of detrimental effects on the health, both social and economic [16].

In this study, the 'social acceptance' dimension of the quality of life showed the highest results, whereas 'school environment' scored the lowest, which could suggest that the teenagers were dissatisfied with their school, and evaluated both the institution and its teachers poorly. Adolescents were accepted by their peers and did not experience distress (bullying) from them. The impact of social acceptance on the quality of life of adolescents is important from the point of view of functioning in a peer environment [17-19].

The results of the analyses carried out allowed acceptance of the hypothesis of the possibility of developing a methodology for defining groups of adolescents with a varying degree of sense of the quality of life. The standard tool, the KIDSCREEN-52 questionnaire, does not offer such a classification; therefore, the study proposed defining groups of adolescents on the basis of a varying sense of quality of life. They were carried out in accordance with the norms regarding the nationwide studies conducted by Mazur in 2003 in the light of KIDSCREEN-52 questionnaire studies KIDSCREEN-52 [18].

The diet adopted in one's childhood and adolescence has an impact on eating habits in adulthood. Currently amongst youth, there is an increase in behavioural patterns in direct opposition to those regarded as healthy behaviours, related to lower physical activity, an array of inadequacies in eating habits, including an irregularity or skipping of basic meals, while simultaneously snacking between them [9-11, 20-22].

While evaluating the physical activity and sedentary behaviours of middle school, high school and university students, Wojtyła-Buciora et al. found that physical education classes are the main physical activity of adolescents during 
the day. With age, adolescents become increasingly less active due to an increase in mostly sedentary activities, in school as well as during their free time. The engagement of teenagers in physical activity in their free time is insufficient. Studies show that according to parents, $60 \%$ of middle school pupils spend every day or almost every day in front of a computer screen, while $62 \%$ watch television [23]. A sedentary lifestyle results in teenagers to become overweight or obese - over $10 \%$ of middle school pupils exhibit excessive weight, while $5 \%$ are obese. The parents of middle school pupils misjudge the weight of their children, most often lowering it. They do not see the problem of obesity in adolescents, claiming that only $8 \%$ of students are overweight [24].

Overweight or obesity is one of the main factors that cause the reduction of social needs during adolescence. This leads to social isolation and the development of emotional disturbances [25-27]. Compared to the objective metric index - BMI - these are very concerning and suggest a high criticism of the participants, especially girls, of their figure and body weight. Even though over half of the girls had an optimal body weight, every second one expressed a desire to reduce body weight. Adolescent girls showed a high need to control their body weight by using different methods for its reduction. Low self-esteem, negative view of one's appearance, and partaking in weight-loss diets may become risk factors of anorectic eating disorders [28].

Analysing the relationship between the subjective sense of the quality of life and BMI, it was found that participants exhibiting a high, medium, as well as low subjective sense of the quality of life, had normal BMI results. Group II - medium subjective sense of the quality of life - had a highest incidence of overweight participants (10.03\%), whereas obesity concerned mostly adolescents in Group I - high subjective sense of the quality of life (9.66\%). Data analysis showed that a small percentage of participants were underweight (2.53\%), most of whom belonged to Group II - medium subjective sense of the quality of life, and least of whom were adolescents in Group III - low subjective sense of the quality of life (0.67\%).

In developed countries, including Poland, there is a constant increase in the occurrence of overweight and obesity, especially among children and adolescents. In Italy, as a part of the HBSC research, a survey was conducted among teenagers, aged 1-15. It was shown that, just like in Poland, boys were more prone to become overweight or obese than girls. Among boys, $28 \%$ of 11 -year-olds, $25 \%$ of 13 -year-olds and $25 \%$ of 15 -year-oldweare either overweight or obese. For girls, this index is equal to $19 \%, 16 \%$ and $12 \%$ for the respective age groups [29]. Studies carried out among Greek students between the ages of 12-19 showed that $19 \%$ of girls and $28 \%$ of boys were overweight, while $6 \%$ of girls and $9 \%$ of boys were obese [30]. In Romania, $16.8 \%$ of boys and $16.3 \%$ of girls were overweight, and $7.8 \%$ of boys and $6.4 \%$ of girls were obese. The frequency of both overweight and obesity were greater for boys than girls [31]. Similar observations were made in Brazil [32]. In Nepal, Koirala et al. examined 986 children aged $6-13$. The analysis showed that $14.6 \%$ of children were overweight, while $11.3 \%$ were obese [33]. In Ukraine, in a study by Dereń et al., 13.9\% of boys and $10.3 \%$ of girls aged $4-18$ were found to be overweight or obese [34]. Overweight and obesity among children and adolescents is also a growing problem in South Asia [35]. Obesity amongst teenagers is therefore currently one of the most frequently occurring problems in the area of public health [36-37].

Throughout adolescence, an image of one's own body is formed, which changes and evolves under the impact of biological, psychological, social and cultural factors. Overweight or obese teenagers often exhibit low self-esteem, a lack of acceptance of their appearance, and have a greater tendency towards depressive states [38]. Excessive body weight also contributes to the development of many illnesses, such as: type 2 diabetes, cardiovascular system diseases, some types of tumours, digestive system diseases and sleep disorders. Obesity, dyslipidaemia, hypertensionand insulin resistance are all constituent elements of Raeven syndrome, a metabolic syndrome $[39,40]$.

Studies undertaken among the adolescents in the Świętokrzyskie province of southeast Poland also included an evaluation of the declared eating habits. Four questions from the HBSC questionnaire related to different aspects of eating habits were selected: dietary patterns, snacking frequency, snacking conten, and the regularity of basic meal consumption. Family meals are an important element in the functioning of a family which enable the formation of beneficial eating behavurs and habits in adolescents, including them eating breakfast. It was proven that adolescents who skip breakfast before leaving the house, compensated for the fact by eating more food during the day.

The studies by Wypych-Ślusarska et al. showed that 59.7\% of the respondents ate breakfast every day before going to school [41]. Skipping this meal in particular was observed at an even greater extent amongst Norwegian - 58\% and Czech $-49 \%$ of teenagers. The studies also showed that the participants who did not eat breakfast in the morning would consume more food during the day $[42,43]$.

The main threat to public health in developed and developing countries alike are the so-called diseases of affluence. One of the main determinants of these diseases is being overweight or obese. There is an increase in the frequency of obesity cases in many countries, which is currently believed to be one of the most important threats to the health of those societies [44]. In the current COVID-19 pandemic, teenage obesity is regarded as one of its main consequences. As far as public health is concerned, physical activity and the eating habits of children and adolescents are particularly important $[45,46]$

The frequency of being overweight and obesity in childhood has a significant relationship with the health condition of young people, as well as middle aged people and partially even of the elderly. Childhood obesity is related to a greater risk of diabetes development, cardiovascular diseases and many types of tumors in adults. It is also tied to a greater risk of the occurrence of psychosocial and emotional struggles. There are few national studies concerning the spread of overweight and obesity and the quality of life of pupils aged 12-14. Employing a simple, standardized and systematic system of monitoring is very important to fill the currently existing gap in the data related to nutrition, and to counteract the obesity epidemic amongst adolescents and risk groups.

It should be noted that any negligence in the period of adolescence relating to the quality of life of teenagers, related to all aspects of one's physical, psychological and social well-being and including important aspects of the standards of living and the environment, will have an effect on the 
health condition of young people, and in the future a big impact on their health and fitness in adulthood and future generations.

\section{CONCLUSIONS}

1. For the most part, adolescents from the Świętokrzyskie province exhibited a high subjective sense of the quality of life, determined by the variance in gender and age of the teenagers.

2. The physical development of the participants was mostly appropriate and consistent with a high subjective sense of the quality of life and exhibited eating habits.

3. To achieve a further improvement in the quality of life of young people, a more coherent model of health policy linked to the objectives of education and social policy should be developed. Such an approach will increase the sense of security, improve the quality of life of young people, and consequently, strengthen the health of the young population.

\section{Acknowledgements}

Project financed under the program of the Minister of Science and Higher Education called "Regional Initiative of Excellence" in the years 2019-2022, project no. 024/ RID/2018/19, amount of financing 11999 000,00 zł.

\section{REFERENCES}

1. Krawczyńska J, Łukawska P. Health-related quality of life of adolescents in the context of selected somatic development indices. Medical Studies. 2016; 32: 189-195. doi: 10.5114/ms.2016.62310.

2. Clark Ch, Paunovic K. WHO Environmental Noise Guidelines for the European Region: A Systematic Review on Environmental Noise and Quality of Life, Wellbeing and Mental Health. Int J Environ Res Public Health. 2018; 15(11): 2400. https://doi.org/10.3390/ijerph15112400

3. Wong FY, Yang L, Yuen JWM, Chang KKP, Wong FKY. Assessing quality of life using WHOQOL-BREF: a cross-sectional study on the association between quality of life and neighborhood environmental satisfaction, and the mediating effect of health-related behaviors. BMC Public Health 2018; 18:1113. https://doi.org/10.1186/s12889018-5942-3

4. Gulliver SB, Cohen LM. The Wiley Encyclopedia of Health Psychology. In: Ustjanauskas AE, Malcarne VL. Health-Related Quality of Life. 2020; 4:149-154. https://doi.org/10.1002/9781119057840.ch198.

5. Zięba M, Cisoń- Apanasewicz U. Jakość życia w naukach medycznych. Piel Opiece Długotermin. 2017; 3: 57-62. doi: 10.19251/pwod/2017.3(6), www.pwod.pwszplock.pl

6. Jasińska M, Sikorski M, Wójcik T, Chmielewski J, Florek-Łuszczki M, Radosław Sierpiński R, Szpringer M, Nowak-Starz G. A subjective sense of the quality of life in adolescents from the świętokrzyskie province. Int J Occup Med Environ Health 2021; 34(3): 1-11. https:// doi.org/10.13075/ijomeh.1896.01696.

7. Cisińska A. Nawyki żywieniowe łódzkich gimnazjalistów. Pielęg Pol. 2017; 3: 437-442. https://doi.org/10.20883/pielpol.2017.58

8. Decyk-Chgcel A. Zwyczaje żywieniowe dzieci i młodzieży. Probl Hig Epidemiol. 2017; 98(2): 103-109. http://www.phie.pl/pdf/phe-2017/ phe-2017-2-103.pdf

9. Nix RL, Francis LA, Feinberg ME, Gill S, Jones DE, Hostetler ML, Stifter CA. Improving Toddlers' Healthy Eating Habits and Self-regulation: A Randomized Controlled Trial. Pediatrics 2021; 147(1): e20193326. https://doi.org/10.1542/peds.2019-3326

10. Kadera M, Sundbloma E, Elinde LS. Effectiveness of universal parental support interventions addressing children's dietary habits, physical activity and bodyweight: A systematic review. Prev Med. 2015; 77: 52-67. doi: 10.1016/j.ypmed.2015.05.005

11. Yasuko Furuichi Y, Sakakibara T, Nezu S, Saeki K, Obayashi K, Kurumatani N, Hoshida T, Doi T, Miki N, Kinoshita S, Shima M.
Analysis of factors related to low health-related quality of life in children with epilepsy using a self-assessed Japanese version of the KIDSCREEN-52. Brain Dev. 2021; 43: 78-88. https://doi.org/10.1016/j. braindev.2020.07.002

12. Barrio J, Cilleruelo ML, Román E, Fernández C. Health-related quality of life in Spanish coeliac children using the generic KIDSCREEN-52 questionnaire. Eur J Pediatr. 2018; 177: 1515-1522. https://doi. org/10.1007/s00431-018-3204-0

13. Sundar TKB, Riiser K, Småstuen MC, Opheim R, Løndal K, Glavin K, Helseth S. Health-related quality of life among 13-14-year old adolescents with overweight - a mixed methods approach. Health Quality Life Outcomes 2020; 18:161. https://doi.org/10.1186/s12955020-01413-0

14. Hirschfeld G, von Brachel R, Thiele Ch. Screening for health-related quality of life in children and adolescents: Optimal cut points for the KIDSCREEN-10 for epidemiological studies. Quality Life Res. 2020; 29: 529-536. https://doi.org/10.1007/s11136-019-02324-4

15. Müller M, Haenni Hoti A. Item analysis of the KIDSCREEN-10 using Rasch modeling. Health Qual Life Outcomes 2020;18: 342. https://doi. org/10.1186/s12955-020-01596-6

16. Boldyreva U, Streiner D, Rosenbaum P, Ronen G. Quality of life in adolescents with epilepsy, cerebral palsy and population norms. Dev Med Child Neurol 2020; 62(11): 1336-1339. https://onlinelibrary.wiley. com/doi/epdf/10.1111/dmcn.14450

17. Zięba E, Krawczyńska J, Zięba P, Strzelecka A, Nowak-Starz G. Dobrostan a rozwój i zdrowie dzieci i młodzieży. In: Uwarunkowania jakości życia w zdrowiu dziewcząt z zaburzeniami miesiączkowania w okresie adolescencji ze środowiska miejskiego na tle zdrowych rówieśniczek w świetle kwestionariusza KIDSCREEN-52. MarkockaMączka K, Król H, editors. Wydawnictwo Naukowe NeuroCentrum. Lublin 2016; 16: 241-250.

18. Mazur J, Małkowska-Szkutnik A, Dzielska A, Tabak I. Polska wersja kwestionariuszy do badania jakości życia związanej ze zdrowiem dzieci i młodzieży (KIDSCREEN). IMiDz. Warszawa 2008.

19. Krawczyńska J,Zięba E,ZiębaP, Nowak-StarzG. Umiejscowieniekontroli zdrowia i samoocena zdrowia młodzieży szkół ponadgimnazjalnych. Probl Pielęg. 2014; 22: 445-452.

20. Korwin-Szymanowska A, Tuszyńska L, Zachowania żywieniowe jako nieodłączny element edukacji zdrowotnej - raport z badań. In: Znaczenie racjonalnego żywienia w edukacji zdrowotnej. WolskaAdamczyk A, editor. Warszawa: WSIiZ; 2015. p. 23-38.

21. Myszkowska-Ryciak J, Harton A, Lange E, Laskowski W, Gajewska D. Nutritional Behaviors of Polish Adolescents: Results of the Wise Nutrition - Healthy Generation Project. Nutrients 2019; 11(7): 1592. doi: $10.3390 /$ nu11071592

22. Wypych-Ślusarska A, Czech E, Kasznia-Kocot J, Słowiński J, Niewiadomska E, Skrzypek M, Malinowska-Borowska J. Health inequalities among students of lower secondary schools in Bytom, Poland. Ann Agric Environ Med. 2018; 25(1): 4-8. doi: https://doi. org/10.5604/12321966.1232771

23. Wojtyła-Buciora P, Stawińska-Witoszyńska B, Wojtyła K, Klimberg A, Wojtyła C, Wojtyła A, Samolczyk-Wanyura D, Marcinkowski JT. Assessing physical and sedentary lifestyle behaviours for children and adolescents living in a district of Poland; What are the key determinants to improving health. Ann Agric Environ Med. 2014; 21(3): 606-612. https://doi.org/10.5604/12321966.1120611

24. Wojtyła-Buciora P, Stawińska-Witoszyńska B, Klimberg A, Wojtyła A, Goździewska M, Wojtyła K, Piątek J, Wojtyła C, Sygit M, Ignyś I, Marcinkowski JT. Nutrition-related health behaviours and prevalence of overweight and obesity among Polish children and adolescents. Ann Agric Environ Med. 2013; 20(2): 332-340.

25. Weichselbaum E, Buttriss J. Diet, nutrition and schoolchildren: An update. Nutrition Bulletin. 2014; 39: 9-73. https://doi.org/10.1111/ nbu. 12071

26. Mazur J. Zdrowie i zachowania zdrowotne młodzieży szkolnej w Polsce na tle wybranych uwarunkowań socjodemograficznych. Wyniki badań HBSC 2014. Warszawa: IMiDz; 2015.

27. Kleszczewska D, Dzielska A, Nałęcz H. et al. Physical activity, BMI and body weight perception among 15-year-old boys and girls in Poland in the light of international comparisons. Dev Period Med. 2017; 21(3): 235-247.

28. Wojtyła-Buciora P, Klimberg A, Wojtyła A. Samoocena własnej sylwetki a wskaźnik masy ciała młodzieży w Polsce. Probl Hig Epidemiol. 2018; 99(2): 146-154.

29. Lazzeri G, Giacchi MV, Spinelli A, et al. Overweight among students aged 11-15 years and its relationship with breakfast, area of residence and parents' education: results from the Italian HBSC 
2010 cross-sectional study. Nutr J. 2014; 5(13): 69. doi: 10.1186/14752891-13-69

30. Grammatikopoulou MG, Poulimeneas D, Gounitsioti IS, et al. ADONUT Study Group. Prevalence of simple and abdominal obesity in Greek adolescents: the ADONUT study. Clin Obes. 2014; 4(6): 303-8. https://doi.org/10.1111/cob.12070

31. Mocanu, V. Prevalence of overweight and obesity in Urban Elementary School Children in Northeastern Romania: Its relationship with socioeconomic status and associated dietary and lifestyle factors. Biomed Res Int. 2013: 1-7. https://doi.org/10.1155/2013/537451

32. Casagrande D, Waib P H, Sgarbi J A. Increase in the prevalence of abdominal obesity in Brazilian school children (2000-2015). IJPAM 2017; 4(4): 133-137. https://doi.org/10.1016/j.ijpam.2017.10.002

33. Koirala M, Khatri RB, Khanal V, Amatya A. Prevalence and factors associated with childhood overweight/obesityof private school children in Nepal. Obes Res Clin Pract. 2015; 9(3): 220-227. https:// doi.org/10.1016/j.orcp.2014.10.219

34. Dereń K, Nyankovskyy S, Nyankovska O, Łuszczki E, Wyszyńska J, Sobolewski M, Mazur A. The prevalence of underweight, overweight and obesity in children and adolescents from Ukraine. Sci Rep. 2018; 8: 3625. https://doi.org/10.1038/s41598-018-21773-4

35. Mistry SK, Puthussery S. Risk factors of overweight and obesity in childhood and adolescence in South Asian countries: a systematic review of the evidence. Public Health. 2015; 129(3): 200-209. https:// doi.org/10.1016/j.puhe.2014.12.004

36. Klatka M, Zienkiewicz E, Kołłątaj W, Zienkiewicz T, Kołłątaj B. Socioeconomic development, level of urbanization and consumption of selected food products as factors in the prevalence of overweight and obesity among youths and young adults in Poland. Ann Agric Environ Med. 2020; 27(1): 139-145. https://doi.org/10.26444/aaem/112373

37. Suliburska J, Bogdański P, Pupek-Musialik D, Głód-Nawrocka M, Krauss H, Piątek J. Analysis of lifestyle of young adults in the rural and urban areas. Ann Agric Environ Med. 2012; 19(1): 135-139.
38. Wojtyła-Buciora P, Bołdowski T, Wojtyła C, Żukiewicz-Sobczak W, Juszczak K, Chęcińska-Maciejewska Z, Wojtyła A, Krauss H. National survey of body mass and dietary behaviour for middle school, high school and university students. J Health Inegual. 2017; 3(1): 64-69. http://dx.doi.org/10.5114/jhi.2017.69168

39. Lizończyk I, Jośko-Ochojska J. Relationship between overweight, obesity and sleep disorders in adolescents from selected cities of Upper Silesia, Poland. Ann Agric Environ Med. 2021; 28(1): 193-197. doi: 10.26444/aaem/118706.

40. Yanovski J. Pediatric obesity. An introduction. Appetite. 2015; 93:3-12. doi: 10.1016/j.appet.2015.03.028

41. Wypych-Ślusarska A, Czech E, Kasznia-Kocot J, Słoiński J, Kowalska $\mathrm{M}$, et al. Socio-economic status and feeding habits of students in lower secondary schools in Bytom. Environ Med. 2013; 16(4): 43-51.

42. Stea TH, Torstveit MK. Association of lifestyle habits and academic achievement in Norwegian adolescents: a crosssectional study. BMC Public Health. 2014;14: 829.

43. Szczepańska E, Deka M, Całyniuk B. Studies to determine nutrition behaviour amongst middle school pupils living in the border areas of Poland and Czech Republic. Rocz Panstw Zakl Hig. 2013; 64(3): 191-196.

44. Kędzior A, Jakubek-Kipa K, Brzuszek M, Mazur A. Trends in prevalence of childhood overweight and obesity on the World, in Europe and in Poland. Pediatr Endocrinol. 2017; 16.1.58: 41-48. doi: 10.18544/ EP-01.16.01.1662

45. Skrzypek M, Krzyszycha RM, Góral K, Szczygieł K, Kowal K, Pokarowski M, Mmora A. Nutritional intervention in the treatment of obesity in children and adolescents. Med Og Nauk Zdr. 2021; 27(1): 13-22. https://doi.org/10.26444/monz/134654

46. Rundle AG, Park Y, Herbstman JB, Kinsey EW, Wang YC. COVID-19_ Related School Closings and Risk of Weight Gain Among Children. Obesity. 2020; 28(6): 1008-1009. https://doi.org/10.1002/oby.22813 